\title{
SILICON AND THIOUREA MEDIATED STIMULATION OF SALT TOLERANCE VARYING BETWEEN THREE FODDER BEET (BETA VULGARIS L.) GENOTYPES
}

\author{
Ali, A. ${ }^{1 *}-$ KhAN, S. U. ${ }^{1}-$ QAYYUM, A. ${ }^{1}-$ BILlAH, M. ${ }^{2}-$ AhMED, W. ${ }^{3}-$ MALIK,.$^{4}$ \\ ${ }^{1}$ Department of Agronomy, The University of Haripur, 22620 Haripur, Pakistan \\ ${ }^{2}$ Department of Soil Science, The University of Haripur, 22620 Haripur, Pakistan \\ ${ }^{3}$ Department of Horticulture, The University of Haripur, 22620 Haripur, Pakistan \\ ${ }^{4}$ Soil and Water Testing Laboratory, 22620 Haripur, Pakistan \\ *Corresponding author \\ e-mail:aqayyum@uoh.edu.pk \\ (Received $6^{\text {th }}$ Mar 2019; accepted $13^{\text {th }}$ Jun 2019)
}

\begin{abstract}
Effect of exogenously applied Silicon (Si) and Thiourea (TU) were examined in fodder beet plants under saline conditions. Seedlings growth of three fodder beet genotypes (Jamon, Monro and Tarine) were maintained in pots containing soil salinized with $300 \mathrm{mM} \mathrm{NaCl}$ dissolved in irrigation water. Two levels of $\mathrm{Si}\left(100 \mathrm{mgL}^{-1}, 200 \mathrm{mgL}^{-1}\right)$ and $\mathrm{TU}\left(150 \mathrm{mgL}^{-1}, 300 \mathrm{mgL}^{-1}\right)$ respectively were applied exogenously through leaves of 40 to 50 days old pots transplanted fodder beet plants. Salinity stress significantly suppressed plant growth and fresh biomass and as well as altered some physiological parameters like total chlorophyll content, $\mathrm{K}^{+}, \mathrm{Na}^{+}$, and $\mathrm{K}^{+} / \mathrm{Na}^{+}$ratio in all the investigated fodder beet genotypes. Yet, these reductions were higher in Tarine followed by Jamon than those of Monro. However, both treatments of $\mathrm{Si}$ and $\mathrm{TU}$ as foliar application were effective in mitigating the adverse effects of salinity stress on shoot growth and improvement in fresh weights of Monro. Salinity stress increased leaf $\mathrm{Na}^{+}$contents, whereas $\mathrm{K}^{+}$contents and $\mathrm{K}^{+} / \mathrm{Na}^{+}$ratio decreased in fodder beet plants under saline regime. These reductions were improved by $\mathrm{Si}$ and $\mathrm{TU}$ application, increased the $\mathrm{K}^{+}$uptake and $\mathrm{K}^{+} / \mathrm{Na}^{+}$ratio through ion selectivity and ultimately triggered activity of anti-oxidant enzymes: Superoxide dismutase (SOD), Peroxidase (POD), and Catalase (CAT) and proline accumulation needed to thrive best in saline stress conditions. The beneficial effects of applied Si and TU were reflected in the form of enhanced fodder beet growth as well as improvement in various physiological traits and antioxidant defensive mechanism.
\end{abstract}

Keywords: fodder beet, winter fodder crop, salt stress, silicon, thiourea

\section{Introduction}

Salinity intrusion is one of the major environmental issues throughout the world and a huge number of hectares of marginal lands also have limited the scope for crop production (Dasgupta et al., 2015). Salinity and drought are two of the most genuine abiotic stresses, which signify a threat on crop productivity worldwide (Guo et al., 2014). In many parts of the world, a significant region of watered arable land has been confronting a major issue of salinization. Even though it is very difficult to accurately determine the increasing salinized area and its phenomenon however, it was estimated that round about $20-21 \%$ of irrigated land (45 million ha) which contributes the on third of the world's coproduction is mainly salt affected (Shrivastava et al., 2015). The productivity of most crops was reduced by soil salinity, in spite of the fact that to a changing degree relying on species (Hussain et al., 2016). Pakistan has about 16.80 million ha irrigated agricultural area in which 6-7\% is categorized as strongly Saline, 9- 
$10 \%$ slightly saline, $3-4 \%$ moderately and $6 \%$ miscellaneous, while $72 \%$ is listed as nonsalt affected land (Khan etal., 2017). Salt stress has great impact on major and minor crop's yield and reduce up to 50\% yield in many arid and semi-arid areas of the world (Dugasa et al., 2016). Production of practically every conventional crop around there is significant decreased under saline soil conditions. Henceforth the introduction of nontraditional salt tolerant fodder crops in these areas could be an appropriate alternative.

Fodder beet is salt tolerant crop when contrasted with other fodder and forages, similar to that it can be effectively grown on salt influenced lands and fed as fodder in numerous European countries and in Egypt. Farmers generally use all parts roots and leaves as animal feed, directly in fresh form or processed (Sakr et al., 2014). The cultivation of fodder beet crop on marginal lands gives a remarkable benefit to farmers in the form of high economic yield production on such type of barren lands (Abdallah et al., 2008). The beet crop is utilized by amalgamation with straw in European and in other different countries of the world. Both the underground part roots and above part leaves are used as animal feed, however the tuberous roots of fodder beet are mainly utilized as primary feed for animals (El-Sarag et al., 2013).

Some beneficial mineral supplements have been determined by different researchers which can balance the unfavorable impacts of salt stress. On earth crust after the oxygen, silicon is found the $2^{\text {nd }}$ most abundant element and exist as $8^{\text {th }}$ common element in nature (Sahebi et al., 2015). A number of ways like fertilizer or bio-stimulant silicon can be used which plays a vital role in plant growth development and yield productivity under various stress conditions (Sawas and Ntatsi, 2015). Silicon supplementation into the solution culture enhanced wheat development and $\mathrm{K}^{+} / \mathrm{Na}^{+}$with reduction in $\mathrm{Na}^{+}$and upgraded $\mathrm{K}^{+}$ take-up. It is useful for plants from numerous points of view as it enhances plant water status in setting of relative water content and transpiration rate, improves the hurtful impacts of salt stress on chlorophyll and plant biomass in both leaves and roots, it brings down fundamentally the $\mathrm{Na}^{+}$uptake by (Liu et al., 2015). The supplementation of Silicon under salt stress conditions has the ability to mitigate the adverse effects of $\mathrm{Na}^{+}$and uptake by plants by increasing the $\mathrm{K}^{+}$concentration and with the resultant increase in $\mathrm{K}^{+} / \mathrm{Na}^{+}$ratio (Xu et al., 2015). Exogenous application of different concentrations of Silicon to salt stressed aloe sensitive plants and tolerant plants significantly improved the $\mathrm{K}^{+}$content in roots and translocation to leaves and other parts of plants consequently raising the $\mathrm{K}^{+} / \mathrm{Na}^{+}$ratio, while decrease the $\mathrm{Na}^{+}$uptake and its translocation (Garg et al., 2016).

Thiourea is a nitrogen and sulfur containing compound and is being utilized for the improvement of crops yield. Addition of thiourea significantly improves plant's root and shoot weight, tallness and number of leaves and leaf area, which directly results in the enhancement of plant's growth and development under various stresses condition (Parveen et al., 2015). Thiourea has the ability to improve entire plant growth, by enhancing cellular development of plants under salt stress (Ikram and Javed, 2015). Saddiqui et al. (2006) also reported that exogenously applied Thiourea altogether enhanced the fresh and dry weights grown under salt stress condition.

The current research was undertaken to test the hypothesis that (1) Thiourea and Silicon exogenous application enhanced fodder beet salt tolerance both by improving the plant biomass and decreasing the ion toxicity; (2) Thiourea and silicon improved the plant water balance by enhancing the proline accumulation; (3) Both treatments alleviated the ion toxicity by triggering antioxidant enzymes which are involved in scavenging reactive oxygen species and ion homeostasis. 


\section{Materials and methods}

\section{Land preparation and nursery raising}

A plot sized $2 \times 2 \mathrm{~m}^{2}$ was prepared for nursery raising of Fodder Beet genotypes. For seeds sowing, the seedbed was prepared by thoroughly mixing one part Farm Yard Manure (FYM) and two parts soil as collected from AP horizon of the Agriculture Research Farm, The University of Haripur. Phosphorus $120 \mathrm{mg} \mathrm{kg}^{-1}$ as single super phosphate and half dose of the nitrogen $\left(60 \mathrm{mg} \mathrm{kg}^{-1} \mathrm{~N}\right)$ as urea were applied as starter dose for fodder beet genotypes at time of Nursery preparation. Remaining $1 / 2$ of the $\mathrm{N}$ was applied in two equal splits, i.e. $30 \mathrm{mg} \mathrm{kg}^{-1} \mathrm{~N}$ was applied 15 days after sowing (DAS) and the remaining at 30 DAS. and the nursery plot was then irrigated immediately. The nursery was left for 45 days after sowing to develop their growth and irrigations were provided at 7 days intervals subsequently.

\section{Pot filling and nursery transplantation}

A surface soil $(0-20 \mathrm{~cm})$, clay loam soil, (Gee and Bauder, 1986) was collected from Agriculture research farm area Department of Agricultural Sciences, The University of Haripur, Pakistan. The soil contained $1.20 \mathrm{mg} \mathrm{Kg}^{-1}$ of total dissolved salts, $0.55 \%$ organic matter (Nelson and Sommers, 1996), 0.20\% calcium chloride (Leoppert et al., 1996), 8.7 $\mathrm{mgL}^{-1}$ available Pphosphorous. Growth media was prepared by filling pots measuring (height $22 \mathrm{~cm}$, base diameter $24 \mathrm{~cm}$ and top diameter $27.5 \mathrm{~cm}$ ) with a mixture of field soil and Farm yard manure in 3:1 ratio. The base of each pot was covered with polyethylene bags in order to develop salinity stress condition.

\section{Plant growth and treatments application}

At field capacity, five plants were transplanted on $1^{\text {st }}$ March, 2017 in each pot, replicated thrice using Completely randomized design (CRD) for each fodder beet variety. In order to develop salinity stress, $300 \mathrm{mM} \mathrm{NaCl}$ solution was applied to the growth medium of Twenty days old transplanted after transplantation in pots Twenty days after transplantation in pots, a dose of $300 \mathrm{mM} \mathrm{NaCl}$ solution was applied to each pot in order to develop salinity stress. All pots were placed in green house and Twenty days after salt application, Calcium silicate (Si) and Thiourea (TU) were applied exogenously on Fodder beet genotypes. Two levels of Si and TU at $100 \mathrm{mgL}^{-1}, 200 \mathrm{mgL}^{-1}$ and $150 \mathrm{mgL}^{-1}, 300$ $\mathrm{mgL}^{-1}$ respectively were applied at 40 days after transplantation in pots, nonetheless one treatment in each fodder beet variety was kept control in the absence of $\mathrm{Si}$ and TU application. At $60^{\text {th }}$ day of transplantation in pots, the plants were harvested and roots were cleaned from soil for data recording of fresh shoot, root weight and length of shoot, root and total biomass. The third fresh leaf of each fodder beet plant was harvested at the end of experiment for $\mathrm{K}^{+}, \mathrm{Na}^{+}$concentration, $\mathrm{K}^{+} / \mathrm{Na}^{+}$ratio, proline content estimation and the activity of antioxidant enzymes (SOD, POD and CAT).

\section{Statistical analysis}

Data of the present study were subjected to analysis using Two-Way ANOVA according to Abdi and Williams (2010), using Statistix 8.1. The differences among means were tested using Tukey's Honest Significant Difference test at $0.01 \%$ probability level. Mean values were presented as mean value with standard errors calculated from three replications. 


\section{Results}

\section{Growth parameters}

Shoot length and root length of all fodder beet genotypes reduced significantly $(\mathrm{P} \leq 0.01)$ under salinity stress (Table 1$)$. However, the reduction in shoot length and root length was much lower in Jamon and Tarine respectively than all other fodder beet genotypes. Exogenously applied Silicon and Thiourea significantly improved the growth of fodder beet genotypes as compared to non-treated plants under salt stress conditions. Silicon and Thiourea increased the shoot length in Monro with Si @ $200 \mathrm{mg} \mathrm{L}^{-1}$ being statistically at par with Tarine under TU @ $300 \mathrm{mg} \mathrm{L}^{-1}$ application. Similarly, the root length of Jamon plants increased under Si @ $100 \mathrm{mg} \mathrm{L}^{-1}$ whereas TU @ $300 \mathrm{mg} \mathrm{L}^{-1}$ application increased root length of Monro plants as compared to other treatments.

Table 1. Growth parameters of fodder beet genotypes grown in saline conditions as affected by exogenous application of silicon and thiourea

\begin{tabular}{|c|c|c|c|c|c|c|}
\hline \multirow[b]{2}{*}{ Parameters } & \multirow[b]{2}{*}{ Genotypes } & \multicolumn{5}{|c|}{ Treatments } \\
\hline & & $\begin{array}{c}\text { Control } \\
(300 \mathrm{mM} \\
\mathrm{NaCl})\end{array}$ & $\begin{array}{c}\mathrm{Si} \\
\left(100 \mathrm{mg} \mathrm{L}^{-1}\right)\end{array}$ & $\begin{array}{c}\mathrm{Si} \\
\left(200 \mathrm{mg} \mathrm{L}^{-1}\right)\end{array}$ & $\begin{array}{c}\text { TU } \\
\left(150 \mathrm{mg} \mathrm{L}^{-1}\right)\end{array}$ & $\begin{array}{c}\text { TU } \\
\left(300 \mathrm{mg} \mathrm{L}^{-1}\right)\end{array}$ \\
\hline \multirow{3}{*}{$\begin{array}{c}\text { Shoot length } \\
(\mathrm{cm})\end{array}$} & & $32.43 \pm 0.34$ & & & $38.97 \pm 0.38$ & $37.23 \pm 0.32$ \\
\hline & Ionro & $36.10 \pm 0.32$ & $38.93 \pm 0.28$ & $44.50 \pm 0.25$ & $37.50 \pm 0.41$ & $38.70 \pm 0.66$ \\
\hline & & $42.36 \pm 0.32$ & $41.90 \pm 0.64$ & $39.33 \pm 0.71$ & $39.80 \pm 0.42$ & $43.90 \pm 0.48$ \\
\hline \multirow{3}{*}{$\begin{array}{l}\text { Root length } \\
(\mathrm{cm})\end{array}$} & & $8.26 \pm 0.08$ & $10.86 \pm 0.08$ & $7.03 \pm 0.12$ & $8.73 \pm 0.18$ & $7.57 \pm 0.09$ \\
\hline & & $8.06 \pm 0.14$ & $9.13 \pm 0.20$ & $7.10 \pm 0.26$ & $8.33 \pm 0.23$ & $9.43 \pm 0.15$ \\
\hline & & $8.33 \pm 0.14$ & $7.36 \pm 0.17$ & $8.90 \pm 0.22$ & $7.63 \pm 0.20$ & $8.47 \pm 0.23$ \\
\hline \multirow{3}{*}{$\begin{array}{c}\text { Shoot } \\
\text { weight (g) }\end{array}$} & & $73.53 \pm 0.65$ & $84.40 \pm 0.82$ & $62.83 \pm 0.62$ & $105.17 \pm 0.42$ & $61.60 \pm 0.93$ \\
\hline & & & & $111.97 \pm 0.92$ & $62.23 \pm 0.64$ & $102.00 \pm 0.72$ \\
\hline & & $65.07 \pm 0.12$ & $62.10 \pm 0.52$ & $58.53 \pm 0.60$ & $54.67 \pm 0.47$ & $49.27 \pm 0.62$ \\
\hline \multirow{3}{*}{$\begin{array}{c}\text { Root weight } \\
\text { (g) }\end{array}$} & & $40.23 \pm 0.26$ & $40.26 \pm 0.71$ & $12.73 \pm 0.55$ & $48.93 \pm 0.49$ & $27.53 \pm 0.52$ \\
\hline & Monro & $35.67 \pm 0.75$ & $39.73 \pm 0.56$ & $50.17 \pm 1.27$ & $39.83 \pm 0.37$ & $58.23 \pm 0.52$ \\
\hline & & $34.66 \pm 1.08$ & $26.50 \pm 0.70$ & $32.13 \pm 0.33$ & $24.40 \pm 0.32$ & $25.73 \pm 0.81$ \\
\hline \multirow{3}{*}{$\begin{array}{c}\text { Total } \\
\text { Biomass }(\mathrm{g})\end{array}$} & Jamon & $103.77 \pm 0.91$ & $134.67 \pm 1.52$ & $117.53 \pm 0.99$ & $154.10 \pm 0.66$ & $89.13 \pm 0.88$ \\
\hline & Monro & $92.50 \pm 1.68$ & $99.53 \pm 1.38$ & $162.13 \pm 1.78$ & $102.07 \pm 0.96$ & $160.23 \pm 0.97$ \\
\hline & Tarine & $79.73 \pm 1.07$ & $98.60 \pm 1.70$ & $90.67 \pm 1.36$ & $79.07 \pm 0.84$ & $95.00 \pm 1.28$ \\
\hline
\end{tabular}

Values in columns having the same letter are not significantly different at $\mathrm{p} \leq 0.05$

Shoot weight and root weight was significantly different $(\mathrm{P} \leq 0.01)$ of all fodder beet plants grown with salinity in root environment (Table 1). However, the reduction in shoot weight and root weight due to root zone salinity was much lower in Tarine compared to other fodder beet genotypes. The exogenous application of silicon and Thiourea significantly affected the fodder beet shoot and root weight under saline conditions. The highest shoot weight and root weight was recorded with Silicon and Thiourea application in Monro which was statistically at par with Jamon. Imposed root zone salinity significantly affected $(\mathrm{P} \leq 0.01)$ the total biomass in fodder beet plants (Table 1). Salinity stress caused maximum reduction in biomass of Tarine plants as 
compared to other fodder beet plants. Both Silicon and Thiourea were found to increase the total biomass under salt stress conditions. Monro produced maximum biomass under Silicon@200 mg L-1 and Thiourea@300 mg L $\mathrm{m}^{-1}$ followed by Jamon under Silicon@ $100 \mathrm{mg} \mathrm{L}^{-1}$ and Thiourea@150 mg L-1 (Fig. 1).

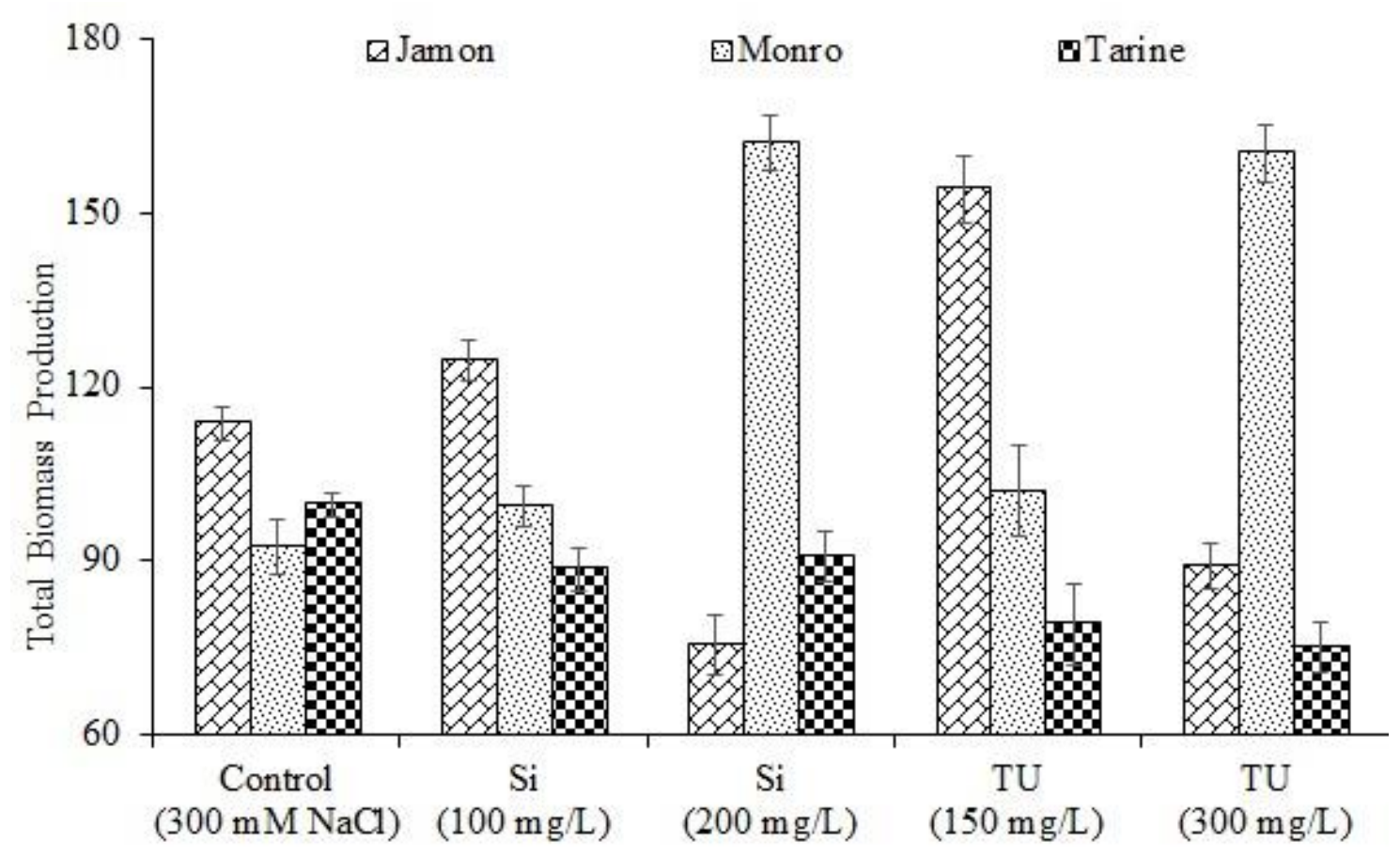

Figure 1. Increase in total biomass production in fodder beet genotypes grown under salt stress conditions at different levels of silicon and thiourea. The bars indicates standard error ( $\pm S E$ ) of mean $(n=3)$. All means are significantly different at $p \leq 0.05$

\section{Physiological parameters}

In all fodder beet plants, the potassium ion concentration was found significantly affected $(\mathrm{P} \leq 0.01)$ under salt stress conditions (Table 2; Fig. 2). The highest $\mathrm{K}^{+}$ concentration was observed in Tarine under salt stress. Plants perform better in $\mathrm{K}^{+}$ions accumulation as Silicon and Thiourea were exogenously applied as compared to control treatment. The higher $\mathrm{K}^{+}$concentration in fodder beet shoots was recorded under exogenous application of Silicon@ $200 \mathrm{mg} \mathrm{L}^{-1}$ and Thiourea @ $150 \mathrm{mg} \mathrm{L}^{-1}$ in Tarine, statistically at par with Monro under control treatment. Root zone salinity significantly $(\mathrm{P} \leq 0.01)$ enhanced the sodium concentration in fodder beet shoots. The maximum $\mathrm{Na}^{+}$ concentration was depicted in Monro under saline conditions. However, Silicon and Thiourea exogenous application were found to decrease the $\mathrm{Na}^{+}$ion accumulation in fodder plants under salt stress conditions as compared to control. Monro recorded with lowest $\mathrm{Na}^{+}$accumulation under Silicon @ $200 \mathrm{mg} \mathrm{L}^{-1}$ statistically at par with Tarine and Jamon under Silicon@100 mg L $\mathrm{m}^{-1}$ and Thiourea@ $300 \mathrm{mg} \mathrm{L}^{-1}$ respectively. Monro recorded highest in $\mathrm{K}^{+} / \mathrm{Na}^{+}$ration under Silicon @ $200 \mathrm{mg} \mathrm{L}^{-1}$ followed by Jamon under Thiourea@150 mg L ${ }^{-1}$ exogenous application respectively. Data revealed significant variation $(\mathrm{P} \leq 0.01)$ among fodder beet genotypes regarding proline accumulation under 
saline conditions (Table 2). Salinity stress significantly reduced proline accumulation in Monro compared to other fodder beet genotypes. Both Silicon and Thiourea were found to positively influence proline accumulation in Fodder beet plants. Deceasing salinity stress also decreased proline accumulation in Tarine under Silicon@100 mg L-1 and Thiourea@300 mg L ${ }^{-1}$, statistically at par with Janom and Monro under Thiourea application@300 mg L ${ }^{-1}$ respectively.

Table 2. Concentration of $\mathrm{K}^{+}, \mathrm{Na}^{+}, \mathrm{K}^{+} / \mathrm{Na}^{+}$ratio, proline content and antioxidant enzyme activities in fodder beet genotypes grown under saline conditions as affected by exogenous application of silicon and thiourea

\begin{tabular}{|c|c|c|c|c|c|c|}
\hline \multirow[b]{2}{*}{ Parameters } & \multirow[b]{2}{*}{ Genotypes } & \multicolumn{5}{|c|}{ Treatments } \\
\hline & & $\begin{array}{c}\text { Control } \\
(300 \mathrm{mM} \mathrm{NaCl})\end{array}$ & $\begin{array}{c}\mathrm{Si} \\
\left(100 \mathrm{mg} \mathrm{L}^{-1}\right)\end{array}$ & $\begin{array}{c}\mathrm{Si} \\
\left(200 \mathrm{mg} \mathrm{L}^{-1}\right)\end{array}$ & $\begin{array}{c}\text { TU } \\
\left(150 \mathrm{mg} \mathrm{L}^{-1}\right)\end{array}$ & $\begin{array}{c}\text { TU } \\
\left(300 \mathrm{mg} \mathrm{L}^{-1}\right)\end{array}$ \\
\hline \multirow{3}{*}{$\begin{array}{c}\mathbf{K}^{+} \\
\text {concentration } \\
\left(\mathrm{mg} \mathrm{g}^{-1}\right)\end{array}$} & Jamon & $76.67 \pm 3.18$ & $94.63 \pm 3.76$ & $86.87 \pm 3.47$ & $88.67 \pm 2.88$ & $102.87 \pm 3.00$ \\
\hline & Monro & $129.17 \pm 7.08$ & $115.87 \pm 5.44$ & $80.50 \pm 6.01$ & $116.80 \pm 5.42$ & $101.90 \pm 4.10$ \\
\hline & Tarine & $123.40 \pm 8.24$ & $96.37 \pm 5.85$ & $138.27 \pm 4.10$ & $141.97 \pm 5.50$ & $122.03 \pm 7.89$ \\
\hline \multirow{3}{*}{$\begin{array}{c}\mathrm{Na}^{+} \\
\text {concentration } \\
\left(\mathrm{mg} \mathrm{g}^{-1}\right)\end{array}$} & Jamon & $56.00 \pm 5.29$ & $48.00 \pm 7.218$ & $63.60 \pm 4.86$ & $56.33 \pm 6.35$ & $61.27 \pm 5.91$ \\
\hline & Monro & $81.57 \pm 10.46$ & $76.57 \pm 7.36$ & $43.10 \pm 8.92$ & $64.37 \pm 2.23$ & $48.97 \pm 6.80$ \\
\hline & Tarine & $105.27 \pm 5.21$ & $54.63 \pm 6.22$ & $94.47 \pm 3.99$ & $116.57 \pm 4.13$ & $77.63 \pm 6.82$ \\
\hline \multirow{3}{*}{$\mathrm{K}^{+} / \mathrm{Na}^{+}$ratio } & Jamon & $1.40 \pm 0.18$ & $1.65 \pm 0.28$ & $1.69 \pm 0.10$ & $2.05 \pm 0.32$ & $1.40 \pm 0.17$ \\
\hline & Monro & $1.65 \pm 0.26$ & $1.85 \pm 0.18$ & $2.20 \pm 0.32$ & $1.52 \pm 0.10$ & $1.94 \pm 0.24$ \\
\hline & Tarine & $1.17 \pm 0.06$ & $1.22 \pm 0.08$ & $1.58 \pm 0.04$ & $1.79 \pm 0.16$ & $1.47 \pm 0.09$ \\
\hline \multirow{3}{*}{$\begin{array}{l}\text { Proline } \\
\text { content } \\
\left(\mathrm{mg} \mathrm{g}^{-1}\right)\end{array}$} & Jamon & $146.67 \pm 3.53$ & $264.33 \pm 2.85$ & $245.67 \pm 4.41$ & $235.67 \pm 4.26$ & $248.33 \pm 2.33$ \\
\hline & Monro & $122.0 \pm 2.52$ & $250.0 \pm 6.08$ & $234.0 \pm 3.18$ & $190.0 \pm 5.03$ & $243.33 \pm 3.06$ \\
\hline & Tarine & $157.33 \pm 5.24$ & $304.67 \pm 5.36$ & $241.67 \pm 2.65$ & $240.67 \pm 7.97$ & $274.0 \pm 7.26$ \\
\hline \multirow{3}{*}{$\underset{\left(\text { unit.mg }^{-1}\right)}{\text { SOD }}$} & Jamon & $154.0 \pm 0.66$ & $167.0 \pm 0.83$ & $196.0 \pm 0.93$ & $195.0 \pm 0.68$ & $178.0 \pm 0.745$ \\
\hline & Monro & $172.0 \pm 0.81$ & $190.0 \pm 0.90$ & $209.0 \pm 0.86$ & $198.0 \pm 0.69$ & $186.0 \pm 0.722$ \\
\hline & Tarine & $164.0 \pm 0.70$ & $197.0 \pm 0.87$ & $201.0 \pm 0.79$ & $191.0 \pm 0.64$ & $184.0 \pm 0.766$ \\
\hline \multirow{3}{*}{$\begin{array}{c}\text { POD } \\
\left(\text { unit.mg }^{-1}\right)\end{array}$} & Jamon & $35.29 \pm 0.40$ & $51.42 \pm 0.73$ & $50.12 \pm 0.61$ & $50.23 \pm 0.66$ & $54.23 \pm 0.810$ \\
\hline & Monro & $36.17 \pm 0.49$ & $51.58 \pm 0.77$ & $50.78 \pm 0.69$ & $51.12 \pm 0.70$ & $54.89 \pm 0.848$ \\
\hline & Tarine & $36.82 \pm 0.52$ & $52.02 \pm 0.79$ & $50.33 \pm 0.68$ & $50.16 \pm 0.60$ & $55.07 \pm 0.866$ \\
\hline \multirow{3}{*}{$\underset{\left(\text { unit.mg }^{-1}\right)}{\text { CAT }}$} & Jamon & $2.65 \pm 0.66$ & $3.01 \pm 0.83$ & $3.84 \pm 0.93$ & $2.69 \pm 0.68$ & $2.89 \pm 0.745$ \\
\hline & Monro & $2.95 \pm 0.81$ & $3.22 \pm 0.90$ & $3.06 \pm 0.86$ & $2.75 \pm 0.69$ & $2.86 \pm 0.722$ \\
\hline & Tarine & $2.81 \pm 0.70$ & $3.09 \pm 0.87$ & $2.98 \pm 0.79$ & $2.59 \pm 0.64$ & $2.93 \pm 0.766$ \\
\hline
\end{tabular}

Values in columns having the same letter are not significantly different at $\mathrm{p} \leq 0.05$

\section{Anti-oxidant enzymatic activities}

Anti-oxidant enzymes activity (SOD, POD and CAT) were significantly affected $(\mathrm{P} \leq 0.01)$ by induced salt stress in all fodder beet genotypes (Table 2; Fig. 3). Highest SOD and POD activity was found in Jamon while Tarine recorded higher CAT activity than rest of the genotypes under imposed salinity stress. Exogenous application of both Silicon and Thiourea enhanced the activity of antioxidant enzymes in fodder beet genotypes under salinity stress than that of untreated plants (control). Nonetheless, SOD, POD and CAT activity were increased significantly in fodder beet plants under Silicon@ $200 \mathrm{mg} \mathrm{L}^{-1}$ and Thiourea @ $150 \mathrm{mg} \mathrm{L}^{-1}$ when applied exogenously under salt stress conditions. 


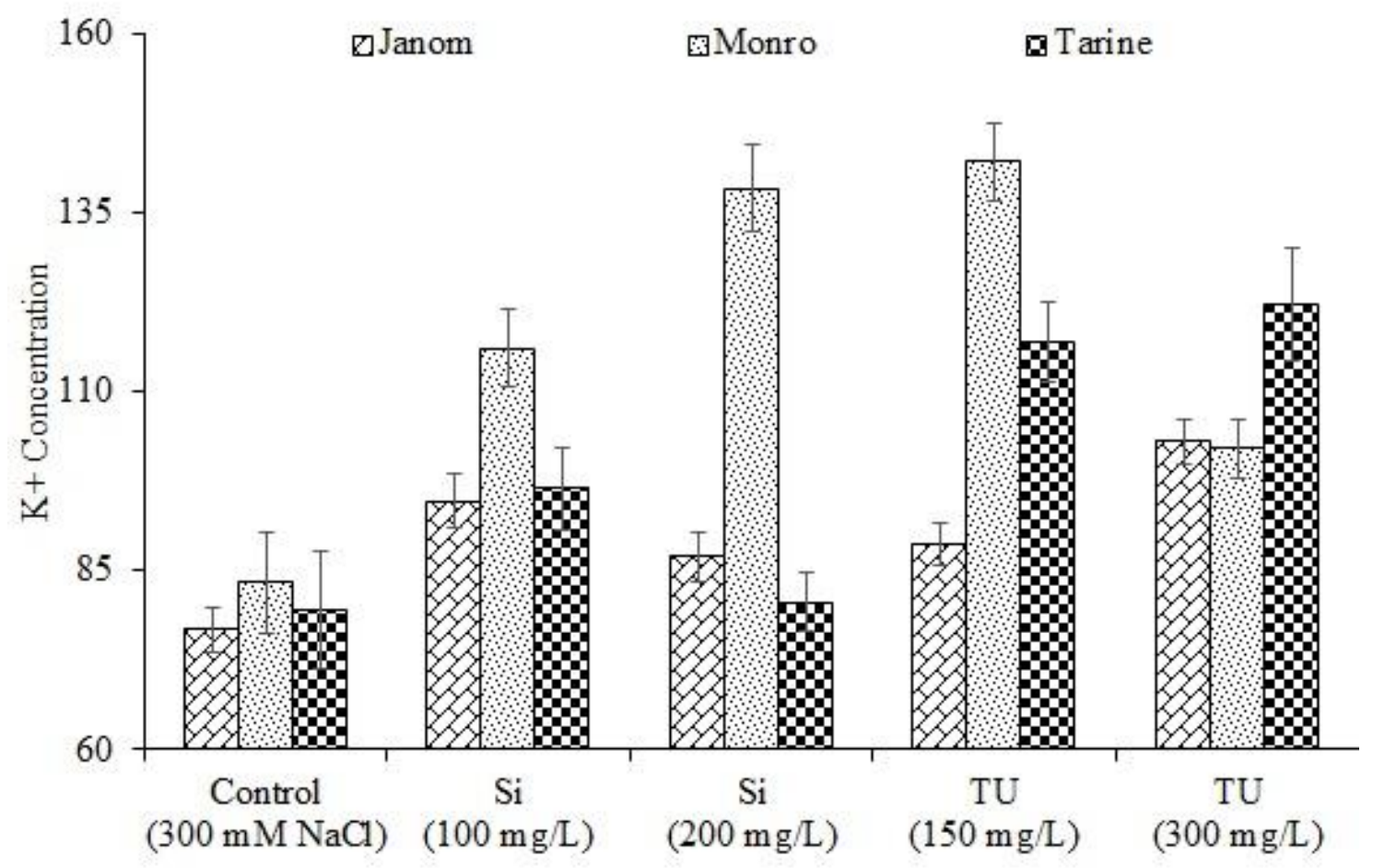

Figure 2. Percent increase in shoot $K^{+}$concentration in fodder beet genotypes grown under salt stress conditions at different levels of silicon and thiourea. The bars indicates standard error $( \pm S E)$ of mean $(n=3)$. All means are significantly different at $p \leq 0.05$

\section{Discussion}

The salinity stressed produced adverse effects on plants growth as mostly expressed as osmotic stress, explicit ion toxicity, damage to cellular membranes, vital nutrient deficiency and trigger in oxidants, etc. (Ashraf, 2009). To overcome salinity stress effects in plants, researchers are using various bio-stimulants which have been reported to influence various physiological processes (Perveen et al., 2014). In current study, the foliar application of silicon and Thiourea enhanced the growth of all Fodder beet plants as grown under salt stress condition. Various growth parameters including root and shoot length, root and shoot fresh weight, and total biomass were enhanced by Silicon and Thiourea under salt stress conditions (Table 1). Similar results to our research study have also been observed (Anjum et al., 2011) in two different wheat genotypes grown under $130 \mathrm{mM}$ salt stress conditions. Likewise, some prior reports supported our results and revealed that Thiourea application mitigates the adverse effects of salinity and hence improved the final grain yield of many crops like, cereal crops (Sahu et al., 2006) and potato (Mani et al., 2012). Various research studies stated that exogenously applied Nitrogen containing compounds e.g. Thiourea has significant impact on the synthesis of green photosynthetic pigments which ultimately associated with high biomass production in salt stress conditions (Ashraf and Harris, 2013). Both Silicon and Thiourea exogenously applied are directly involved in the cellular osmotic adjustment of plants, which leads to enhance the biomass production of plants under salt stress condition (Burman et al., 2004; Seckin et al., 2009). 


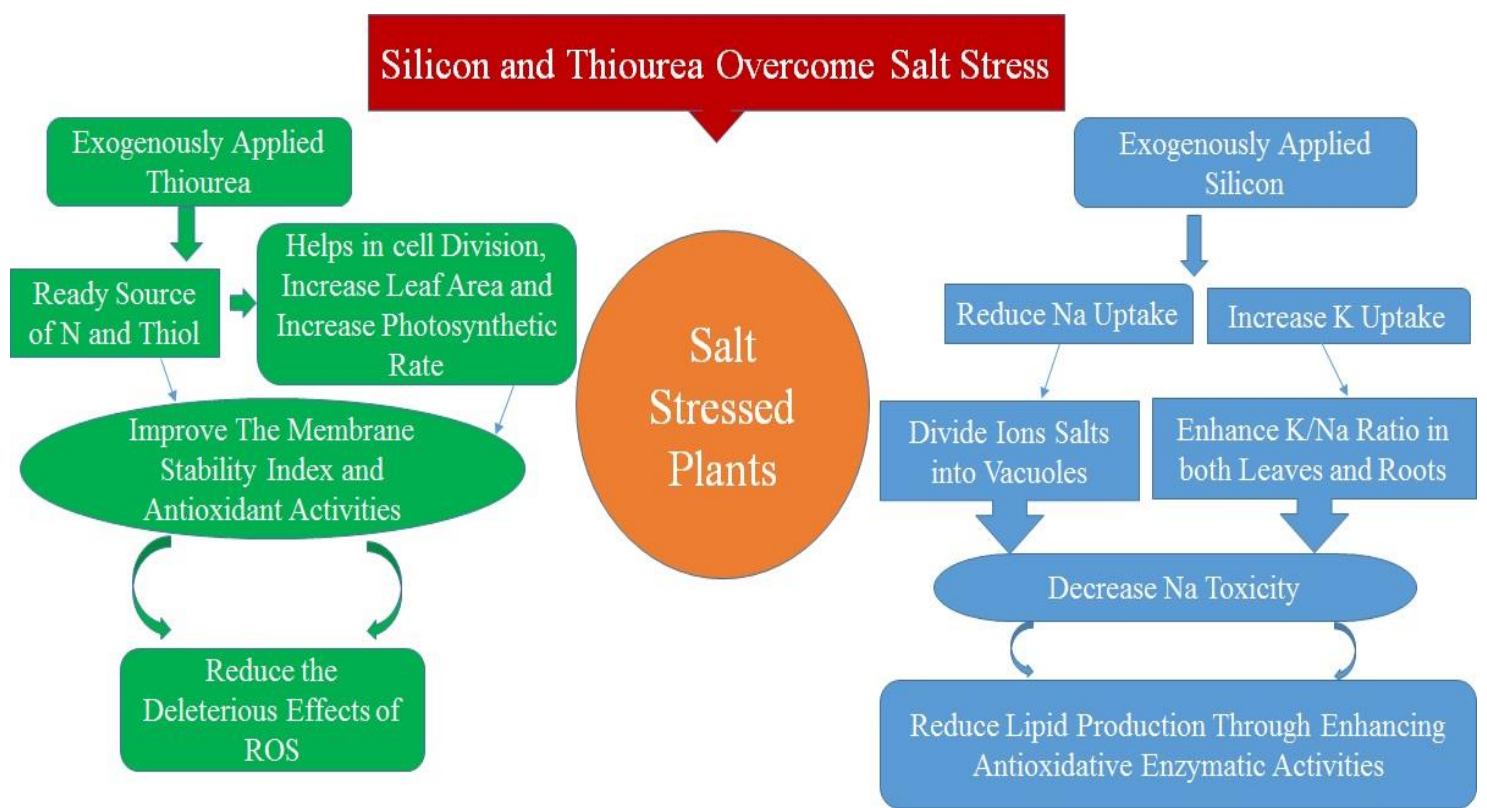

Figure 3. Mechanism of silicon and thiourea mediated salinity tolerance in fodder beet

Present study showed that salt stress caused the increased accumulation of $\mathrm{Na}^{+}$in shoots and roots of fodder beet genotypes. Due to presence of high concentration of $\mathrm{Na}^{+}$ content, reduction was recorded in the concentration of $\mathrm{K}^{+}$which ultimately reduced the $\mathrm{K}^{+} / \mathrm{Na}^{+}$ration in plant's tissues. The physiological window of ideal $\mathrm{K}^{+}$uptake by plants limits within the sight of expanding measure of $\mathrm{Na}^{+}$. In the current research exogenous application of Silicon and Thiourea on fodder beet plants enhanced the $\mathrm{K}^{+}$and $\mathrm{K}^{+} / \mathrm{Na}^{+}$ by reducing $\mathrm{Na}^{+}$uptake (Table 2; Fig. 2). Silicon is also reported as to enhance the $\mathrm{K}^{+} / \mathrm{Na}^{+}$ratio under salt stress (Al-aghabary et al., 2004). A critical decrease saw in $\mathrm{Na}^{+}$ take-up demonstrates that TU-induced tolerance is because of salt stress mitigation strategy (Srivastava et al., 2011). To become salt stress tolerant, plants adopt various strategies and mechanisms like proline accumulation, formation of mannitol and glycine betaine etc which plays an important role in various plants processes just like, scavenging of Reactive Oxygen species in salt stress (Ali and Ashraf, 2011), stabilization of cell's membrane (Ashraf and Ali, 2008) and Osmotic adjustment of plants (Ashraf and Foolad, 2007). In this study, Tarine performed best in proline accumulation under salt stress conditions. Maximum proline content was found by Silicon exogenous application @ $100 \mathrm{mgL}^{-1}$ (Table 2; Fig. 3). Silicon application improves proline and protein accumulation which ultimately trigger antioxidative defense mechanisms and decreases the lipid peroxidation under salt stress (Al-aghabary et al., 2004). Production of Reactive Oxygen Species such as SOD, POD, and hydroxyl radicals mainly damage the plants at cellular level which thrive in saline growth medium (Ashraf et al., 2009). In the current study we have detected that salt stress induces the SOD, POD and CAT activities as to alleviate salt stress in fodder beet plants. The exogenous application of Silicon and Thiourea showed to activate these activities more efficiently against salt stress conditions for ideal plant growth and development (Table 2; Fig. 3). Some prior studies concluded that Thiourea induced enhancement in the activities of antioxidant enzymes like, SOD, POD and CAT with remarkable decrease in Oxidative stress generated by the presence of Salinity stress 
(Hammed et al., 2013). Likewise, another study also suggested that exogenous application of Thiourea in salt stress condition significantly lowered oxidative damage caused by ROS rather than unsprayed plants (Srivastava et al., 2011). It has been demonstrated recently that Silicon mitigates oxidative stress by stimulation of antioxidants, both enzymatic and non-enzymatic (Savvas and Ntatsi, 2015), such as superoxide dismutase (SOD), catalase (CAT), ascorbate peroxidase (APx), peroxidases (POD), and ascorbate (AA) etc. Li et al. (2016) showed that the provision of $\mathrm{Si}$ exogenously increased the SOD, POD and CAT activity of Glycyrrhiza uralensis seedlings grown under salt stress, after 20 days of treatment. Our research findings are analogous to earlier research studies which revealed that exogenously applied silicon can increase the anti-oxidant enzymatic activities such as; superoxide dismutase (SOD), peroxidase (POD) and catalase (CAT) under saline regimes.

\section{Conclusions}

Salt stress caused reduction in growth attributes, physiological and biochemical parameters of fodder beet plants. However, exogenously application of silicon and Thiourea improved to some extent stress tolerance in fodder beet plants by improving growth parameters as well as proline content, $\mathrm{K}^{+}$content, $\mathrm{K}^{+} / \mathrm{Na}^{+}$ratio and decreasing $\mathrm{Na}^{+}$content in the shoots under saline conditions. Among all the three fodder beet genotypes evaluated under salt stress condition, Monro performed best having maximum SOD, POD and CAT activities. It was able to thrive best under saline conditions and hence produced prolific biomass, followed by Jamon and Tarine respectively. Furthermore; Silicon@ $200 \mathrm{mgL}^{-1}$ and Thiourea @ $150 \mathrm{mgL}^{-1}$ was found most effective in mitigating the salt stress conditions. To further investigate the salt ameliorating ability of silicon and Thiourea, a field experiment with more number of fodder beet genotypes is suggested.

Compliance with ethical standards. There is no potential conflict of interests and authors confirm that the field studies did not involve endangered or protected species.

\section{REFERENCES}

[1] Abdallah, E. F., Yassen, A. A. (2008): Fodder beet productivity under fertilization treatments and water augmentation. - Australian Journal of Basic and Applied Sciences 2: 282-287.

[2] Abdi, H., Williams, L. J. (2010): Newman-Keuls Test and Tukey Test. - In: Salkind, N. J. (ed.) Encyclopedia of Research Design. Sage, Thousand Oaks, CA, pp. 1-11.

[3] Al-aghabary, K., Zhu, Z., Shi, Q. (2004): Influence of silicon supply on chlorophyll content, chlorophyll fluorescence, and antioxidative enzyme activities in tomato plants under salt stress. - Journal of Plant Nutrition 27(12): 2101-2115.

[4] Ali, Q., Ashraf, M. (2011): Induction of drought tolerance in maize (Zea mays L.) due to exogenous application of trehalose; growth, photosynthesis, water relations and oxidative defence mechanism. - Journal of Agronomy and Crop Science 197(4): 258-271.

[5] Anjum, F., Wahid, A., Farooq, M., Javed, F. (2011): Potential of foliar applied thiourea in improving salt and high temperature tolerance of bread wheat (Triticum aestivum). International Journal of Agriculture and Biology 13(2): 25-39. 
[6] Ashraf, M. (2009): Biotechnological approach of improving plant salt tolerance using antioxidants as markers. - Biotechnology Advances 27(1): 84-93.

[7] Ashraf, M., Ali, Q. (2008): Relative membrane permeability and activities of some antioxidant enzymes as the key determinants of salt tolerance in canola (Brassica napus L.). - Environmental and Experimental Botany 63(3): 266-273.

[8] Ashraf, M., Foolad, M. (2007): Roles of glycine betaine and proline in improving plant abiotic stress resistance. - Environmental and Experimental Botany 59(2): 206-216.

[9] Ashraf, M., Harris, P. J. C. (2013): Photosynthesis under stressful environments. An overview. - Photosynthetica 51: $163-190$.

[10] Burman, U., Garg, B. K., Kathju, S. (2004): Interactive effects of thiourea and phosphorus on clusterbean under water stress. - Biologia Plantarum 48(1): 61-65.

[11] Dasgupta, S., Hossain, M. M., Huq, M., Wheeler, D. (2015): Climate change and soil salinity: the case of coastal Bangladesh. - Ambio 44(8): 815-826.

[12] Dugasa, T., B. Bebie, R. P., Tomer, S., Barnabas, J. (2016): Effect of seed priming on salt tolerance of bread wheat (Triticumaestivum L.) varieties tesfayedugasa. - Journal of Scientica 6(3): 139-153.

[13] El-Sarag, E. I. (2013): Response of fodder beet cultivars to water stress and nitrogen fertilization in semi arid regions. - American-Eurasian Journal of Agricultural \& Environmental Sciences 13: 1168-1175.

[14] Garg, N., Bhandari, P. (2016): Interactive effects of silicon and arbuscular mycorrhiza in modulating ascorbate-glutathione cycle and antioxidant scavenging capacity in differentially salt-tolerant Cicer arietinum L. genotypes subjected to long-term salinity. Protoplasma 253(5): 1325-1345.

[15] Gee, G. W., Bauder, J. W. (1986): Particle Size Analysis. - In: Klute, A. (ed.) Methods of Soil Analysis, Part 1: Physical and Mineralogical Methods. $2^{\text {nd }}$ Ed. American Society of Agronomy Madison, Wisconsin pp. 383-412.

[16] Guo, J., Ling, H., Wu, Q., Xu, L., Que, Y. (2014): The choice of reference genes for assessing gene expression in sugarcane under salinity and drought stresses. - Scientific Reports 4: 70-42.

[17] Hameed. A., Jafri, L., Sheikh, M. A. (2013): Effect of thiourea on proteins, catalase, guaiacol peroxidase and protease activities in wheat leaves under $\mathrm{H}_{2} \mathrm{O}_{2}$ induced oxidative stress. - Iranian Journal of Plant Physiology 4: 857-864.

[18] Hussain, M. I., Lyra, D. A., Farooq, M., Nikoloudakis, N., Khalid, N. (2016): Salt and drought stresses in safflower: a review. - Agronomy for Sustainable Development 36(1): 4.

[19] Ikram, S., Javed, F. (2015): Cadmium stress alleviation by thiourea in barley. International Journal of Innovation and Applied Studies 12(2): 384.

[20] Khan, M., Shafi, M., Bakht, J., Anwar, S. (2017): Effect of salinity and seed priming on growth characters of wheat varieties. - Sarhad Journal of Agriculture 33(3): 435-446.

[21] Liu, P., Yin, L., Wang, S., Zhang, M., Deng, X., Zhang, S., Tanaka, K. (2015): Enhanced root hydraulic conductance by aquaporin regulation accounts for silicon alleviated saltinduced osmotic stress in Sorghum bicolor L. - Environmental and Experimental Botany 111: 42-51.

[22] Li, Y. T., Zhang, W. J., Cui, J. J., Lang, D. Y., Li, M., Zhao, Q. P., Zhang, X. H. (2016): Silicon nutrition alleviates the lipid peroxidation and ion imbalance of Glycyrrhiza uralensis seedlings under salt stress. - Acta Physiologiae Plantarum 38(4): 96.

[23] Loeppert, R. H., Suarez, D. L. (1996): Carbonate and Gypsum. - In: Sparks, D. L., Page, A. L., Helmke, P. A. (eds.) Methods of Soil Analysis. Part 3: Chemical Methods. American Society of Agronomy Madison, WI, pp. 437-474.

[24] Mani, F., Bettaieb, T., Zheni, K., Doudech, N., Hannachi, C. (2012): Effect of hydrogen peroxide and thiourea on fluorescence and tuberization of potato (Solanum tuberosum L.). - Journal of Stress Physiology and Biochemistry 8(3): 14-19. 
[25] Nelson, D. W., Sommers, L. E. (1996): Total Carbon, Organic Carbon, and Organic Matter. - In: Sparks, D. L., Page, A. L., Helmke, P. A. (eds.) Methods of Soil Analysis. Part 3: Chemical Methods. American Society of Agronomy Madison, WI, pp. 961-1010.

[26] Perveen, A., Wahid, A., Mahmood, S., Hussain, I., Rasheed, R. (2015): Possible mechanism of medium-supplemented thiourea in improving growth, gas exchange, and photosynthetic pigments in cadmium-stressed maize (Zea mays). - Brazilian Journal of Botany 38(1): 71-79.

[27] Perveen, S., Shahbaz, M., Ashraf, M. (2014): Triacontanol-induced changes in growth, yield, leaf water relations, oxidative defense system, minerals, and some key osmoprotectants in Triticum aestivum under saline conditions. - Turkish Journal of Botany 38(5): 896-913.

[28] Sahu, M. P., Kumawat, S. M., Ramaswamy, N. K., D’souza, S. F., Singh, G. (2006): Sulphydryl bioregulator technology for increasing wheat productivity. - Research Bulletin RAU-BARC 3: 1-56.

[29] Sakr, H. O., Awad, H. A., Seadh, S. E., Abido, W. A. E. (2014): Influence of irrigation withholding and potassium levels on forage yields and its quality of fodder beet. Journal of Crop Science 5(1): 116-125.

[30] Savvas, D., Ntatsi, G. (2015): Biostimulant activity of silicon in horticulture. - Scientia Horticulturae 196: 66-81.

[31] Seckin, B., Sekmen, A. H., Türkan, I. (2009): An enhancing effect of exogenous mannitol on the antioxidant enzyme activities in roots of wheat under salt stress. - Journal of Plant Growth Regulation 28(1): 12.

[32] Shrivastava, P., Kumar, R. (2015): Soil salinity: a serious environmental issue and plant growth promoting bacteria as one of the tools for its alleviation. - Saudi Journal of Biological Sciences 22(2): 123-131.

[33] Siddiqui, Z. S., Shaukat, S. S., Zaman, A. U. (2006): Alleviation of salinity-induced dormancy by growth regulators in wheat seeds. - Turkish Journal of Botany 30(5): 321330.

[34] Srivastava, A. K., Srivastava, S., Penna, S., D’Souza, S. F. (2011): Thiourea orchestrates regulation of redox state and antioxidant responses to reduce the $\mathrm{NaCl}$-induced oxidative damage in Indian mustard (Brassica juncea (L.) Czern.). - Plant Physiology and Biochemistry 49(6): 676-686.

[35] Xu, C. X., Ma, Y. P., Liu, Y. L. (2015): Effects of silicon (Si) on growth, quality and ionic homeostasis of aloe under salt stress. - South African Journal of Botany 98: 26-36. 